\title{
Development and Sensory Evaluation of Chat Prepared by Germinated Legumes
}

\author{
Reema Devi $^{* *}$ and Darshan Punia ${ }^{2}$ \\ ${ }^{1}$ Department of Foods and Nutrition, ${ }^{2}$ Department of Foods and Nutrition, Chaudhary \\ Charan Singh Haryana Agricultural University, Hisar, Haryana- India \\ *Corresponding author
}

\section{A B S T R A C T}

\begin{tabular}{|l|}
\hline Key w o r d s \\
$\begin{array}{l}\text { Chat, Legumes, } \\
\text { Germination }\end{array}$ \\
\hline Article Info \\
\hline $\begin{array}{l}\text { Accepted: } \\
\text { 12 January } 2021 \\
\text { Available Online: } \\
\text { 10 February } 2021\end{array}$ \\
\hline
\end{tabular}

In the present study five types of chat were prepared. Control chat was prepared using potato, cucumber and tomato in the ratio 50:35:15. The chat prepared from germinated legumes viz. green gram, moth bean, chickpea and lentil were given the names as type-I, type-II, type-III and type-IV, respectively. The type-I, type-II, type-III and type-IV chat were compared with control chat. The sensory evaluation was done by semi-trained panel members using nine-point hedonic scale. The results of the present study showed that mean scores for colour, appearance, aroma, texture, taste and overall acceptability of chat (control) were 7.30, 7.30, 7.40, 7.20, 7.40 and 7.32, respectively which fell in the category of "liked moderately" type-I chat were "liked extremely", whereas, sensory scores of typeII chat were $8.40,8.40,8.50,8.40,8.40$ and 8.42 for colour, appearance, aroma, texture, taste and overall acceptability, respectively, which fell in the category of "liked very much". Type-III chat and type-IV chat was "liked very much" by the panel of judges. The overall acceptability scores showed that all types of chat were liked very much, whereas control was liked moderately.

\section{Introduction}

Legume grains occupy an important place in human nutrition, especially in low-income groups of people living in developing countries. Legumes not only add variety to human diet but also serve as an economical source of supplementary proteins (20-30 per cent of protein) for a large population in developing countries like India where majority of the population is vegetarian (Tresina et al., 2014).
Legumes are subjected to various processing techniques such as soaking, germination, boiling, autoclaving, fermentation and other processing methods prior to consumption. Germination is simple and inexpensive process which improves the palatability, digestibility and availability of certain nutrients (Kumar et al. 2011). It is the most effective way to enhance the bioactive compounds of the legumes (Mbithi-Mwikya et al., 2000; VidalValverde et al., 2003). Sprouts have fairly large nutritional benefits for the human body because of their high 
concentration of nutrients which can be used readily by the body (Randhir et al., 2004). Vitamin $\mathrm{C}$ is an excellent antioxidant, especially in a food system to maintain the active state for many bioactive compounds, such as vitamin $\mathrm{E}$, phenolics and flavonoids (Guo et al., 2012).

Singh et al., (2016) evaluated the sensory attributes of chaat prepared with germinated (GSF) sorghum grains and found that chaat was "liked very much" by majority of panel members. The sensory scores of chaat for colour, appearance, flavour, texture, taste and overall acceptability were 8.3, 8.0, 7.4, 7.5, 7.9 and 7.8, respectively. Ladoo containing 40per cent GSF secured maximum score for colour (7.9), appearance (7.8), flavour (7.9), texture (7.6), taste (8.2) and overall acceptabilty (7.8) as compared to 20 and 60per cent GSF containing ladoo. Mean scores of all developed ladoos reported that 40 per cent GSF incorporated ladoo was most acceptable by the panel members.

In the present study an attempt was made to prepare chat using different legumes and conducted a sensory evaluation.

\section{Materials and Methods}

The present study was carried out in the Department of Foods and Nutrition, I.C College of Home Science, Chaudhary Charan Singh Haryana Agricultural University, Hisar (Haryana).

The commonly consumed varieties of whole legumes namely green gram (MH-421), chickpea (HC-1) and lentil (Sapna) were procured in a single lot from the Pulse Section, Department of Genetics and Plant breeding, College of Agriculture, Chaudhary Charan Singh Haryana Agricultural University, Hisar. Moth bean was procured in a single lot from local market of Hisar city.
The cleaned legumes grains were washed with water and soaked for overnight. After soaking the remaining water was drained off and grains were germinated. Germination was carried out at $37^{\circ} \mathrm{C}$ in orbital incubator for $18 \mathrm{hr}$.

Five types of chat were prepared. Control chat was prepared using potato, cucumber and tomato in the ratio 50:35:15. The chat prepared from germinated legumes viz. green gram, moth bean, chickpea and lentil were given the names as type-I, type-II, type-III and type-IV, respectively. The type-I, type-II, type-III and type-IV chat were compared with control chat.

\section{Method of Chat Preparation}

Potatoes, cucumber, tomato, green chilli and coriander leaves were washed.

Washed potatoes were boiled, peeled and cut into small pieces.

Cucumber and tomato were cut into small pieces.

All the germinated legumes were washed, steamed for 15 minute and kept separately.

Then potatoes, cucumber and tomato were added to the germinated steamed legumes and mixed properly.

Onion, salt, green chilli, chat powder and coriander leaves were added to the prepared mixture and served.

\section{Results and Discussion}

The results of the present study showed that mean scores for colour, appearance, aroma, texture, taste and overall acceptability of chat (control) were 7.30, 7.30, 7.40, 7.20, 7.40 and 7.32 , respectively which fell in the category of "liked moderately". The organoleptic scores for colour, appearance, aroma, texture, taste and overall acceptability in type-I chat were $8.50,8.60,8.30,8.20,8.50$ and 8.42 , 
respectively. The scores for colour, aroma, texture, taste and overall acceptability fell in the category of "liked very much", whereas score for appearance fell in the category of "liked extremely".

The sensory scores of type-II chat were 8.40, $8.40,8.50,8.40,8.40$ and 8.42 for colour, appearance, aroma, texture, taste and overall acceptability, respectively, which fell in the category of "liked very much". Sensory evaluation results showed that type-III chat was "liked extremely" in terms of appearance (8.60) while "liked very much" in terms of colour (8.50), aroma (8.50), texture (8.20), taste (8.20) and overall acceptability (8.40). Type-IV chat was "liked very much" in terms of colour (8.40), aroma (8.20), texture (8.30), taste (8.30) and overall acceptability (8.36). The appearance (8.60) was "liked extremely" by the panel of judges. The overall acceptability scores showed that all types of chat were liked very much, whereas control was liked moderately.

Table.1 Ingredients used for preparation of chat

\begin{tabular}{|l|c|c|c|c|c|}
\hline \multirow{2}{*}{ Ingredients } & \multicolumn{5}{|c|}{ Quantity } \\
\cline { 2 - 6 } & Control & Type-I & Type-II & Type-III & Type-IV \\
\hline $\begin{array}{l}\text { Potato(boiled), cucumber and } \\
\text { tomato }\end{array}$ & $50 \mathrm{~g}, 35 \mathrm{~g}, 15 \mathrm{~g}$ & $20 \mathrm{~g}, 10 \mathrm{~g}, 5 \mathrm{~g}$ & $20 \mathrm{~g}, 10 \mathrm{~g}, 5 \mathrm{~g}$ & $20 \mathrm{~g}, 10 \mathrm{~g}, 5 \mathrm{~g}$ & $20 \mathrm{~g}, 10 \mathrm{~g}, 5 \mathrm{~g}$ \\
\hline Germinated green gram(GGG) & - & $65 \mathrm{~g}$ & - & - & - \\
\hline Germinated moth bean(GMB) & - & - & $65 \mathrm{~g}$ & - & - \\
\hline Germinated chickpea (GC) & - & - & - & $65 \mathrm{~g}$ & - \\
\hline Germinated lentil (GL) & - & - & - & - & $65 \mathrm{~g}$ \\
\hline Onion & $5 \mathrm{~g}$ & $5 \mathrm{~g}$ & $5 \mathrm{~g}$ & $5 \mathrm{~g}$ & $5 \mathrm{~g}$ \\
\hline Salt & $2 \mathrm{~g}$ & $2 \mathrm{~g}$ & $2 \mathrm{~g}$ & $2 \mathrm{~g}$ & $2 \mathrm{~g}$ \\
\hline Green chilli & $1 \mathrm{~g}$ & $1 \mathrm{~g}$ & $1 \mathrm{~g}$ & $1 \mathrm{~g}$ & $1 \mathrm{~g}$ \\
\hline Coriander leaves & $1 \mathrm{~g}$ & $1 \mathrm{~g}$ & $1 \mathrm{~g}$ & $1 \mathrm{~g}$ & $1 \mathrm{~g}$ \\
\hline Chat powder & $0.5 \mathrm{~g}$ & $0.5 \mathrm{~g}$ & $0.5 \mathrm{~g}$ & $0.5 \mathrm{~g}$ & $0.5 \mathrm{~g}$ \\
\hline
\end{tabular}

Table.2 Sensory Evaluation of different types of chat

\begin{tabular}{|c|c|c|c|c|c|c|}
\hline \multirow[t]{2}{*}{ Products } & Colour & Appearance & Aroma & Texture & Taste & $\begin{array}{c}\text { Overall } \\
\text { Acceptability }\end{array}$ \\
\hline & \multicolumn{6}{|c|}{ Scores } \\
\hline $\begin{array}{l}\text { Control (C) } \\
\text { (P:C:T::50:35:15) }\end{array}$ & $7.30 \pm 0.15$ & $7.30 \pm 0.15$ & $7.40 \pm 0.22$ & $7.20 \pm 0.13$ & $7.40 \pm 0.16$ & $7.32 \pm 0.10$ \\
\hline $\begin{array}{l}\text { Type-I } \\
\text { (C: GGG ::35:65) }\end{array}$ & $8.50 \pm 0.22$ & $8.60 \pm 0.16$ & $8.30 \pm 0.21$ & $8.20 \pm 0.20$ & $8.50 \pm 0.22$ & $8.42 \pm 0.17$ \\
\hline $\begin{array}{l}\text { Type-II } \\
\text { (C:GMB::35:65) }\end{array}$ & $8.40 \pm 0.22$ & $8.40 \pm 0.22$ & $8.50 \pm 0.22$ & $8.40 \pm 0.16$ & $8.40 \pm 0.22$ & $8.42 \pm 0.17$ \\
\hline $\begin{array}{l}\text { Type-III } \\
\text { (C:GCP::35:65) }\end{array}$ & $8.50 \pm 0.22$ & $8.60 \pm 0.16$ & $8.50 \pm 0.22$ & $8.20 \pm 0.13$ & $8.20 \pm 0.20$ & $8.40 \pm 0.14$ \\
\hline $\begin{array}{l}\text { Type-IV } \\
\text { (C:GL::35:65) }\end{array}$ & $8.40 \pm 0.22$ & $8.60 \pm 0.16$ & $8.20 \pm 0.20$ & $8.30 \pm 0.15$ & $8.30 \pm 0.15$ & $8.36 \pm 0.14$ \\
\hline $\mathrm{CD}(\mathrm{P} \leq 0.05)$ & 0.60 & 0.50 & 0.62 & 0.45 & 0.55 & 0.41 \\
\hline $\begin{array}{l}\text { Values are mean } \pm \mathrm{SE} \\
\mathrm{C}=\mathrm{Con} \text { trol } \\
\mathrm{GGG}=\text { Germinated } \mathrm{Gr} \\
\mathrm{GCP}=\text { Germinated } \mathrm{Ch}\end{array}$ & independent d & $\begin{array}{l}\text { rminations } \\
\text { PCT=Potato, Cucu } \\
\text { GMB=Germinated } \\
\text { GL= Germinated L }\end{array}$ & $\begin{array}{l}\text { and tomato } \\
h \text { bean }\end{array}$ & & & \\
\hline
\end{tabular}


Fig.1 Legumes used in study

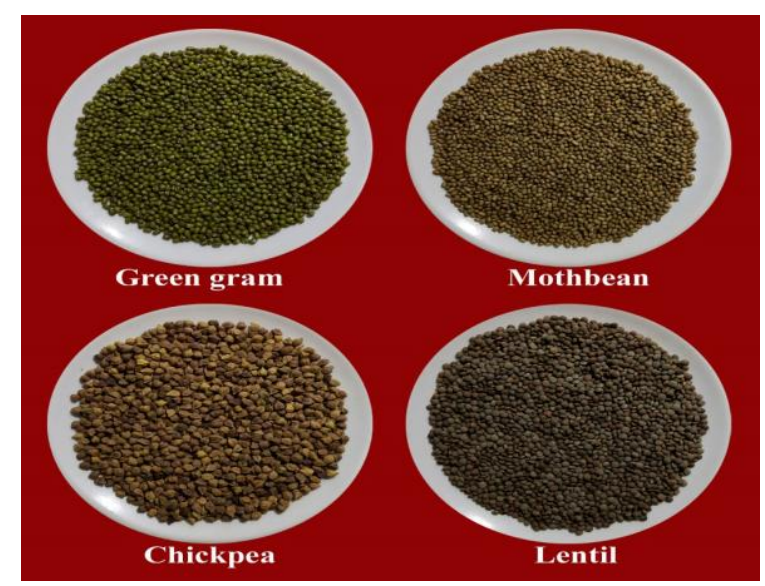

Fig.2 Types of $C H A T$

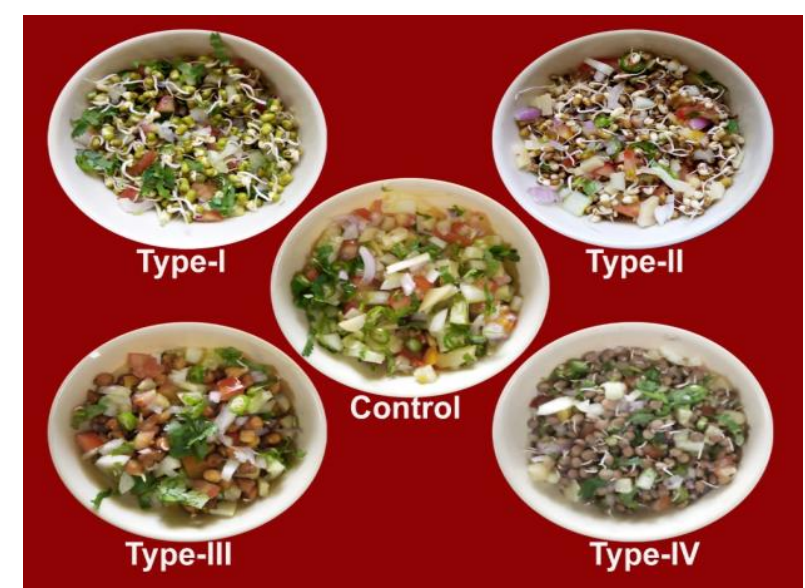

$\mathrm{C}=$ Control (Potato, cucumber + tomato)

Type-I $=\mathrm{C}+$ Germinated green gram $(35: 65)$

Type-III $=\mathrm{C}+$ Germinated chickpea $(35: 65)$

Type-II = C+ Germinated moth bean $(35: 65)$

Type-IV $=\mathrm{C}+$ Germinated lentil $(35: 65)$
Many people are surprised to know about how nutritious legumes are. They contain protein, fiber, carbohydrate, B vitamins, iron, copper, magnesium, manganese, zinc and phosphorous. Legumes are naturally low in fat, are practically free of saturated fat, and because they are plant foods, they are cholesterol free as well. One serving of legumes, which is one-half cup, provides about 115 calories, $20 \mathrm{~g}$ of carbohydrate, 7-9 $\mathrm{g}$ of fiber, $8 \mathrm{~g}$ of protein, and $1 \mathrm{~g}$ of fat. Legumes also have a low glycemic index, generally ranging between 10 and 40.Along with being a highly nutritious food, evidence shows that legumes can play an important role in the prevention and management of a number of health conditions. The nutritional benefit of including legume sprouts in one's eating plan is that they are low in calories and carbohydrate. For example, 1 cup of raw mung bean sprouts (which shrinks to $1 / 2$ cup cooked bean sprouts) contains just 31 calories and $6 \mathrm{~g}$ of carbohydrate, along with $2 \mathrm{~g}$ of fiber and $3 \mathrm{~g}$ of protein. So With the present study we can suggest that instead of eating road side chat which is prepared from potato and other such ingredient which have plenty of carbohydrates, can suggest the chat prepared with different legumes i.e. mung bean, moth bean, lentil and chickpea. 
It can be concluded that germination is beneficial processing technique. The chat developed by different germinated legumes were well accepted. The protein content of raw mung bean was 27.6 per cent after germination it was increased to 29.4 per cent. The moisture, fat and ash content of raw mung bean were 9.9, 1.9 and 3.5 per cent, respectively, after germination the moisture, fat and ash content of mung bean were 6.0, 2.0 and 3.2 per cent, respectively (Skylas et al., 2018).Therefore germinated legumes can serve as an important ingredient in preparation of various food products. Mung bean sprouts also provide vitamin $\mathrm{C}$, vitamin $\mathrm{K}$ and folate. Nutrition has moved from being viewed only as a preventive modality to being recognized as a disease management tool. Incorporating healthy nutrition into both your own life and your clinic routines might be a meaningful change that you can implement one bite at a time.

\section{References}

Guo, X., Li, T., Tang, K. and Liu, R.H. 2012. Effect of germination on phytochemical profiles and antioxidant activity of mung bean sprouts (Vigna radiata). Journal of Agricultural and Food Chemistry, 60: 11050-11055.

Kumar, B., Verma, S.K., and Singh, H.P. 2011. Effect of temperature on seed germination parameters in Kalmegh (Andrographis paniculata Wall. ex Nees.).Industrial Crops and Products, 34(1): 1241-1244.

Mbithi-Mwikya, S., Van Camp J., Yiru Y. and Huyghebaert A. 2000. Nutrient and antinutrient changes in finger millet (Eleusine coracan) during sprouting. Food Science and Technology, 33: 9-14.

Randhir, R., Lin, Y.T. and Shetty K. 2004. Stimulation of phenolics, antioxidant and antimicrobial activities in dark germinated mung bean sprouts in response to peptide and phytochemical elicitors. Process Biochemistry, 39: 637-646.

Singh, V., Sati, V. and Agarwal, S.(2016.Potential of germinated sorghum (sorghum bicolor) for utilization as a health food. International Journal of Science, Environment and Technology,5(5): 4203-4212.

Skylas, D.J., Molloy, M.P., Willows, R.D., Salman, H., Blanchard, C.L. and Quail, K.J. 2018. Effect of Processing on Mungbean (Vigna radiata) flour nutritional properties and protein composition. Journal of Agricultural Sciences, 10(11): 16-28.

Tresina, P.S., Daffodil, E.D., Lincy, P. and Mohan, R.V. 2014. Assessment of biochemical composition and nutritional Potential of three varieties of (Vigna radiata L.). Bio Life, 2(2): 655-667.

Vidal-Valverde, C., Fri'as, J., Sierra, I., Blazquez, I., Lambien, F. and Kuo, Y. H. 2003. New functional legume food by germination: Effect on the nutritive value of beans, lentils and peas. European Food Research and Technology, 215: 472-476.

\section{How to cite this article:}

Reema Devi and Darshan Punia. 2021. Development and Sensory Evaluation of Chat Prepared by Germinated Legumes. Int.J.Curr.Microbiol.App.Sci. 10(02): 112-116. doi: https://doi.org/10.20546/ijcmas.2021.1002.013 